\title{
Academic Deanship in a Post Pandemic Institution
}

\author{
Kenneth M. Coll ${ }^{1}$ \& Charles P. Ruch ${ }^{2}$ \\ ${ }^{1}$ Dr. Coll, Professor, Former Dean, College of Education, former Acting Dean, School of Social Work, University of \\ Nevada, Reno, USA \\ ${ }^{2}$ Dr. Ruch, Former Dean, Boise, Idaho, USA \\ Correspondence: Dr. Kenneth M. Coll, Professor, Former Dean, College of Education, former Acting Dean, School of \\ Social Work, University of Nevada, Reno, USA.
}

Received: February 4, 2021

doi:10.5430/ijhe.v10n5p132
Accepted: May 10, 2021

Online Published: May 10, 2021

URL: https://doi.org/10.5430/ijhe.v10n5p132

\begin{abstract}
The challenges to higher education institutions resulting from the COVID-19 pandemic are placing new and demanding pressures on the academic deanship. A leadership role focusing on guiding teams of professionals toward meeting internally defined goals now requires critical examination. This study analyzes the impact of the pandemic on higher education institutions and particularly the academic deanship. A model for the deanship in a post pandemic institution is included.
\end{abstract}

Keywords: deans, pandemic, innovations, planning, challenges, enrollment, finances, programming

\section{Introduction}

Well before the arrival of the pandemic, calls for serious change in institutional practices echoed. In a recent analysis, the Boston Consulting Group cited numerous challenges to colleges and universities (Henry, Pagano, Puckett \& Wilson, 2014). These include tensions to halt tuition increases, to show proof of a college degree's return on investment, to better account for student outcomes (i.e., retention, job placements), to implement better business delivery models [including on-line and virtual], and to produce more revenue so as to remain financially sustainable. Additionally, recent campus unrest and pressures to deal with diversity in all its dimensions came to the fore offering further challenges and demands for systemic change (Kezar, Fries-Britt, Kurban, McGuire \& Wheaton, 2018). As Major (2020) noted "the virus has, simply put, disrupted the status quo, and it has been unlike anything we've experienced in modern times" p.435.

Academic deans exist in that difficult place between the intentions of central administration, the state, donors, the community, and the needs of faculty and students. In that environment academic deans are expected to be trailblazers in balancing internal and external demands. Internal stressors come from the institution itself as budgets are squeezed, enrollments shift, and accreditation and accountability mount. External stressors come from employers that hire the graduates, policymakers at all levels, and think-tanks, both supportive and critical of higher education (English \& Kramer, 2017).

The arrival of the COVID-19 pandemic was a sudden disruptor of gigantic proportions. Institutions were forced to shift instruction to remote delivery, and to close most or all activities, services and campus facilities. Essentially higher education was forced to quickly move from the heart of the collegiate experience - a face to face, group-oriented organization-- to a remote, individualized, and highly technology intensive organization. Each institution struggled with response decisions to deal with this crisis. Deans and Chairs were expected to facilitate mandated changes quickly, often with no experience or needed skills to guide such actions (Flaherty, 2016, December 1; Wepner, Hopkins, Jackson, \& Damico, 2012; Wepner, Henk, \& Lovall, 2015).

Institutions attacked the consequences of the disruption with differing levels of understanding and commitment. Of most concern was the immediate - next semester or year. The possibility that the institution would never return to its former configuration received little attention. What the college would look like and what would be the role, skill sets, and approach expected of the academic deanship, post pandemic, should be a matter of immediate concern.

This study examines current views of post pandemic higher education and postulates what the academic deanship must look like if it is to contribute to institutional viability going forward. 


\section{Challenges to Higher Education and the Deanship_-Pre-pandemic.}

Given the myriad of institutional types characterized by different missions, governance, financial structure, and service areas, challenges facing individual schools were of differing impact. However, all institutions faced the impact of three mega trends: [a]student demographics and enrollment, [b] program content and delivery, and [c] the business model. The interrelationship among these trends results in a different challenge to each school.

\section{Enrollment challenges}

Higher education enrollments are changing. The number of high school graduates has been on the decline impacting first time enrollments. Retention and completion rates have been less that desired. Enrollment demographics highlighted significant differences across racial, ethnic, gender, and age. International student enrollment was declining. Increased cost, declining student support, and increased student debit have added more pressure to declining enrollment. (Bransberger, 2018; Pelletier,2016; WICHE, 2018, 2020)

\section{Program content and delivery}

The 'value proposition' for a collegiate degree was being seriously challenged. The perceived or real disconnect between student and societal needs and collegiate offerings were under scrutiny or attack. The tensions between education with a career focus versus education for broader self-fulfillment questioned the role of the liberal arts, especially the humanities and social sciences. Concurrently, the mode of delivery; face to face, through technology or some combination was resulting in increased competition among colleges. The 'collegiate experience,' the hallmark of the residential institution, was challenged by on-line competitors such as Western Governors University, University of Maryland Global Campus, Grand Canyon University. Many institutions increasingly elected to include on-line offerings in addition to face to face instruction. (Gallagher \& Palmer, 2020, October).

\section{Business plan}

The confluence of these two mega trends directly impact the financial structure of each institutions. Private institutions depend on tuition/fees driven by enrollment. Discounting strategies were straining, endowments challenged, and other revenue streams limited. Public institutions confronted limited tuition/fee increases, declining governmental support, and challenges to fundraising and auxiliary revenue. Increased competition for students pressured all institutions to expand investments in facilities, technology, and student support. This environment of increased expenses and declining revenues resulted in calls to revise the institutional 'business plan' (Askin \& Shea, 2016; Lapovisky, 2016; Sheets, Crawford, \& Soares, 2012).

Prior to the arrival of the COVID-19 pandemic, every college and university were dealing with the impact of these three mega trends. Guided by institutional mission, aspiration, and significant stakeholder pressures, small, and large changes were conceptualized and implemented. Major changes were guided by presidents, provosts and Boards. However, it was at the unit level that such changes needed to be implemented. Deans were expected to be on the front line of institutional reform.

This environment was also having an impact on the deanship and individual deans. Reduced resiliency of academic deans brought on by these pressures prior to COVID has been increasingly acknowledged as a confounding factor for exigent change (Ammons, 2017; Coll, Niles, Coll, Ruch \& Stewart, 2018; Wepner, Hopkins, Clark Johnson, \& Damic o, 2012). One national academic dean's group put it this way, "Deans confront, in virtual isolation and often with inadequate preparation, an array of challenges. The challenges multiply when deans attempt to move beyond the status quo and lead change efforts within their institutions to move from organizations focused on compliance to ones focused on outcomes." (Deans for Impact, 2015, p. 1). The consequences for academic deans pre-pandemic have often been over-commitment, reduced hardiness, and burnout (Coll, Niles, Coll, Ruch \& Stewart, 2019).

Differing views of the role of the dean were articulated. New expectations for the performance of deans emerged. Dean as manager, entrepreneurial leader, fundraiser, challenged to more traditional role as academic leader. (Arntzen, 2016; Cleverley-Thompson, 2015; Schlichtmeier, 2019).

In sum, as the COVID-19 pandemic arrived, colleges and universities were responding to profound pressures to change; academic deans were challenged to lead in this new environment.

\section{Views of Post Pandemic Higher Education}

The pandemic impacted all higher education in early 2020. In a matter of a weeks, colleges and universities were forced to suspend campus instruction and move to a remote learning mode. Students were sent home, campus facilities and activities closed and canceled. Staff furloughed or worked from home. Communication shifted to technology. Conditions and plans to 're open' were unclear. While Boards, Presidents and other senior administrators wrestled with 
an unpredictable environment, deans were challenged to provide leadership, support and guidance to their disrupted units. In an analysis of the initial impact of the coronavirus across colleges and universities. Kelly and Columbus (2020) noted that all were consumed with adjusting to this new reality, with plans and activities almost always focused on 'getting thought' the disruption and a return to the 'status quo ante'.

Given clear evidence in the summer of 2020 that the pandemic will not easily end, planning for the contingency that the institution may never return to its former configuration is currently of high import. The level of institutional denial of such a future, coupled with the differing impact of the pandemic on institutional type texture current and future analysis and planning. While the exact nature of colleges and universities post pandemic is unknown, the same mega trends prior to the disruption are in evidence.

Recent studies and analysis present a variety of future institutional models. Post pandemic higher education will take different tacks, dependent on institutional mission and circumstances. For example, Radecki \& Schonfeld (October 20, 2020] recently examined the impact and future for research intensive universities, while Volk \& Benedix (2020) considered the future of the liberal arts college. And Lester (2020) outlines a plan for future community colleges.

Kim and Maloney (2020) suggest alternatives for the 'low-density' university, that is students and faculty and staff returning to campus post pandemic at full capacity but adapting to a variety of approaches for addressing 'lower' density concerns, from social distancing and remote instruction to Hi-Flex course models, based on differing response to the pandemic challenge. The Deloitte Center for Higher Education Excellence (May 2020) presented scenarios to guide institutional planning 3-5 years out. Built on an analysis of institutional mission, TIAA-EY Parthenon (2020) outline a planning model in the context of capital, human, financial, physical, and reputational. Selingo (2020, October 30 and 2020) argues that there will be several models for the future institution. Student enrollment and cost will drive success. All were clear that attention to affordability, functionality and emotional will be the basic building blocks for institutional success.

Regardless of the model selected, the fiscal impact will texture institutional future. Reyes (August 10, 2020) outlines those complexities and possibilities of each of the possible instructional models; live, remote, or hybrid. All have short term and long-term consequences.

To summarize, professional literature suggests that post pandemic higher education institutions will be characterized by a focused mission, market emphasis, and data driven decision making. A student focused, technology emphasis in programming, and a revised fiscal plan will be required.

\section{Post pandemic Deanship}

While presidents and Boards will lead in institutional planning, academic deans will be expected to lead in the redesign of their unit, consistent with institutional direction. This will require a different model for the academic deanship. Changes in the unit requiring emphasis by the dean are illuminated in the following chart.

\section{ACADEMIC LEADER}

[current]

Unit Mission

Unit Goal

Planning

Mega trends

Enrollment

Programming

Finances

\section{Finances}

Manage current budget

The deanship in a post pandemic institution will require a shift in focus and application of new skill sets. This new view of the deanship starts with a shift from dean as academic leader to dean as college CEO. As CEO, the incumbent will give attention and leadership across the full range of services and functions of the College; serving to focus, articulate and integrate. A careful review of the College mission to assure a clear sense of direction closely aligned with the institution mission will be necessary. This will need to be crafted with input across all impacted, especially relevant external stakeholders.

$$
\begin{aligned}
& \text { close alignment with institutional } \\
& \text { innovation/redesign } \\
& \text { tactical/scenario/cyclic }
\end{aligned}
$$

major concern, recruitment/retention market driven/ technology

remote, hybrid, on-campus

multi/expanded revenue streams

focus budget on mission needs 
As college CEO, the dean will need to lead the unit to adopt a 'culture of innovation.' The College will need to prize programmatic changes in response to student needs and marketplace requirements over previously held goals. Planning will need to be conceptualized around meeting the demands of the post pandemic environment. While tactical planning will be critical to quickly respond to immediate situations, long range planning will utilize scenario tools, understanding that the goal is not to return the College to former times, but plan for new challenges (Santilli \& Wutka, 2020).

Successful Colleges will be highly focused, integrated across functions, and to a much larger extent, responsible for its own student recruitment/retention, programming, and financial affairs. The responsibility of the CEO dean will be to build and maintain operations across these mega trends.

\section{Enrollment}

Higher education enrollment will continue to change. Individual units will need enrollment data and analysis, and plan accordingly. High school populations are declining. International students are also in decline. The pandemic is further challenging enrollments. Willingness to travel distance to school, response model[s] by the college, changing student interests, perceptions, and life situation are additional challenges to enrollment management. Hahn, Halloran, Faklis, \& Dillon (11/22/2020) outline the important functions supporting enrollment management, retention and student experience that will become of import to the CEO dean. Deans will be challenged to provide additional student support services, both during the recruitment and enrollment. Remote advising will need to be implemented as well as a multi-mode communication protocol. (Lundquist, Rice, \& Widenhorn, 2020).

\section{Programming}

The move to remote instruction necessitated by the pandemic will have a continuing impact on individual units. Long term models: face to face, hybrid or remote, require faculty professional development, expanded IT resources, and attention to pedology will require attention. Programming to respond to market demand will become of significant import.

\section{Finances}

Most pandemic colleges will need a revised/new financial plan. Institutional closure declines in enrollment have a direct impact on the bottom line. Depending on mission, institutions may experience revenue decline from auxiliary services, research funding and philanthropic development. Institutions will redesign their business plan. Many will elect budgeting models that move fiscal matters and responsibility to the college. College enrollment will drive college budgets. A more focused college mission will require alternative spending practices at the unit level. Finding additional revenue streams will become a significant CEO dean responsibility. Absent increased revenue, colleges will need to operate with a reduced resource level. Options to assist from the central administration will be limited, if at all.

\section{Conclusion}

The post pandemic college will be different in focus, organization and resources than previously known. Leading in the crafting of this new design, moving toward its implementation, and guiding in its operation will be the new responsibilities of the academic dean. The understanding of the dean as CEO of the college is one view that will meet this challenge.

\section{References}

Arntzen, E. (2016). The Changing Role of Deans in Higher education-From Leader To Manager. Universal Journal of Educational Research, 4(9), 2068-2075, 2016. https://doi.org/10.13189/ujer.2016.040918

Askin, J. A., \& Shea, B. (2016). A White Paper: Possible Futures for Higher Education's Economic Model. Washington, DC.: NACUBO.

Cleverley-Thompson, S. (2016). The Role of Academic Deans as Entrepreneurial Leaders in Educational Institutions. Innov. Higher Educ, 41.75-85. https://doi.org/10.1007/s10755-015-9339-2

Coll, K., Niles. S. G., Coll, K. F., Ruch, C. P., \& Stewart, R. A. (2018). Education Deans: Challenges and Stress. Journal of Organizational \& Educational Leadership, Vol 4: Iss 1, Article 2.

Coll, K., Niles, S. G., Coll, K. F., Ruch, C. P., \& Stewart, R. A. (2019). Academic Deans: Perceptions of Effort-Reward Imbalance, Over-Commitment, Hardiness, and Burnout. International Journal of Higher Education, 8(4), 124-135. https://doi.org/10.5430/ijhe.v8n4p124

Deloitte Center for Higher Education Excellence. (2020, May). Higher education remade by COVID-19: Scenarios for \begin{tabular}{ll|l} 
resilient leaders & $3-5$ & years.
\end{tabular} wwwZ.deloitte.com/us/en/pages/public-sector/articles/covid-19-higher-education-scenario-planning, htm 
English, D., \& Kramer, R. (2017, May 31). Can deans fix higher-education dysfunction? https://www.chronicle.com/article/Can-Deans-Fix-Higher-Ed/240201

Flaherty, G. (2016, December 1). Forgotten Chairs. Inside Higher. http://insiderhighered.com/2016/12/01/new-study-suggests-training-departmen.

Gallagher, S., \& Palmer, J. (2020). The Pandemic Pushed Universities Online. The Change Was Long Overdue. Education

Hahn, S., Halloran, L., Faklis, A., \& Dillon. (2020, November). Enrollment Management, Retention and the Student Experience. Huron Consulting Group https://www.huronconstultinggroup.com/insights/enrollment-management-retention-student experience

Henry, T., Pagano, E., Puckett, J., \& Wilson, J. (2014, April 10). Five trends to watch in higher Education. https://www.bgperspectives.com/content/articles/education_public_sector_five_trends_watch_higher_education/ admnin071.shtml.

Kelly, A. P., \& Columbus, R. (2020, July). College in the time of Coronavirus: Challenges Facing American Higher Education. Washington, D. C., American Enterprise Institute.

Kezar, A., F ries-Britt, S., Kurban, E., McGjier, D., \& Wheaton, M. M. (2018). Speaking Truth and Integrity: Confronting Challenges of Campus Racial Climate. Washington, DC.: American Council on Education.

Kim, J., \& Maloney. (2020). The Low-Density University: 15 scenarios for Higher Education. Baltimore, MD., Johns Hopkins University Press.

Lapovsky, L. (2016). The Higher Education Business Model: Innovation and Financial Sustainability. TIAA_CREF Institute. www.tiaa-crefinstitute.org.

Lester, J. (2020). Tools in a Toolbox: Leading Change in Community Colleges. Washington, DC: American Council on Education.

Lundquist, A. E., Rice, A., \& Widenhorn, M. (2020). The Pandemic College Student Experience: Implications for Student Success and Retention. Anthology Whitepaper. www.anthology.com/paper/the-pandemic-college-student-experience.

Major, C. (2020). Unprecedented Times and Innovation. Innovative Higher Education, 45(6), 435-436. https://doi.org/10.1007/s10755-020-09528-4

Pelletier, S. (2016). Managing Your Enrollment Destiny: Investing for Holistic Change in Enrollment, Revenue and Retention. Washington, DC.: AASCU.

Radecki, J., \& Schonfeld, R. C. (2020, October). The Impacts of COVID-19 on the Research Enterprise: A Landscape Review. ITHAKAS-R. https://doi.org/10.18665/sr.314247

Reyes, B. (2020, August 10). Live, remote, or hybrid? Consider the financial impacts. University Business. https://universitybusiness.com/live-remote-or-hybrid-conider-the-financial-impacts

Santilli, N. R., \& Wutka, S. (2020). An Integrated Approach to Scenario Planning: Recovery Planning in a Volatile Environment: Part l. Ann Arbor, MI., SCUP

Schlichtemeier, K. (2019). Lessons on Effective Leadership from Eight Deans of Schools Education. Journal of Higher Education Management, 34(2), 60-75 (ISSN 2640-751).

Selingo, J. (2020, October 30). What's the Post-Pandemic Future of Higher Ed? Next. https://www.getevue.co/profile/next-jeff-selingo/iddued/what-s-the-post-pandemic-future-of-higher-ed-286546?

Selingo, J. (2020), The New U: The Age of Continuous Connections in Higher Education. https://www.salesforce.org/blog/the-new-university.

Sheets, R., Crawford, S., \& Soares, L. (2012, March). Rethinking Higher Education Busines Models. Washington, DC., Center for American Progress and EDUCAUSE.

TIAA-EY Parthenon. (2020). The new normal: Higher Education in a post-COVID-91 world.

Volk, S., \& Benedix, B. (2020). The Post Pandemic Liberal Arts College: A Manifesto for Reinvention. Cleveland, OH., Belt Publishing.

Wepner, S. B., Hopkins, D., Clark Johnson, V., \& Damico, S, B. (2012). Outlasting the Revolving Door: Resiliency in the Deanship. Journal of Higher Education Management, 27(1). 
Wepner, S. B., Henk, W., \& Lovell, S. (2015). Developing Deans as Effective Leaders for Today's Educational Landscape. Journal of Higher Education Management, 30(1), 51-64.

\section{Copyrights}

Copyright for this article is retained by the author(s), with first publication rights granted to the journal.

This is an open-access article distributed under the terms and conditions of the Creative Commons Attribution license (http://creativecommons.org/licenses/by/4.0/). 